\title{
Environmental Impact of Shrimp Culture at Gwatr Culture Site in Chabahar, Sistan-Baluchestan Province \\ Valiallahi Jalal $^{1 *}$, Mokhtari Alireza²
}

${ }^{1}$ Environmental Science Department, Shahid Rajaee Teacher Training University, Lavizan, Tehran, Iran

${ }^{2}$ Department of Fisheries, Islamic Azad University of Bandar Abbas, , Bandar Abbas, Iran

\begin{abstract}
Present study carried out in Gwuatr shrimp culture Site and Gwatr Bay in east of Chabahar city, Sistan and Baluchestan province. In this project five stations including supply channel, drainage channel, valve outlet, estuary of Gwatr and the Gwatr Gulf were selected to determine physical and chemical factors such as temperature, salinity, dissolved oxygen, total phosphorus and total nitrogen and $\mathrm{pH}$. Sampling conducted once during the shrimp culturing period and monthly at other times. The main objective of this study is surveying change in environmental condition because of biological and non-biological effluents of Gwatr shrimp culture site on coastal waters of Chabahar. We observed that there is a significant difference among chemical and physical factors between different stations (ANOVA, $P \leq 0.05$ ). In conclusion although there was no thermal pollution in this site, but extending aquaculture activities increased the average of salinity and $\mathrm{pH}$ and pollutant in the drainage channels, so environmental health conditions needs to be controlled and monitored by the environmental experts, otherwise, present status may go to undesirable condition or state of emergency.
\end{abstract}

Keywords: Waste characters; Shrimp farms; Environmental parameters; Sustainable development; Gwatr Bay

\section{Introduction}

Worldwide, brackish-water aquaculture production (4.7 million tons) consisted of crustaceans (57\%), freshwater fishes (19\%), diadromous fishes (15\%), marine fishes (7\%), and marine molluscs (2\%) in 2010; more than $99 \%$ of the crustaceans were marine shrimps [1]. Uncontrolled growth aquaculture industry, in addition to the use of natural resources is necessary to disrupt the natural balance to determine the proper proliferation and development of aquaculture with the environment and control pollution. Growers in countries the industry, much research is done on its effect on the environment [2]. Shrimp farm effluent can be a source of pollution in the sea [3].

Effluent includes water replacement during the growing period, sewage from pond and washing out water from pond in periods of harvest. Wastewater entering the sea, likely increase nutrients and suspended particles may lead to the following risk of high nitrification, reducing light penetration, and there may lead changes in benthic fauna and sediment characters, etc. [4]. Negative environmental impacts of wastewater include changes in water and soil quality, ecological change, the incidence of diseases introduced by non-native species and changes in the genetic diversity [5]. In 1988, unstable environment of modern breeding and rearing shrimp is close to the farms in Taiwan. This turning point for decision making and to pay more attention judicial authorities in India to social and economic values of the industry and the owner of the industrial countries have done research in this area, including Thailand [6], Indonesia [7], Australia [8] and American [9]. It shows the importance of research about the effect of shrimp farming on the environment, Sarà [10] with water pollution from shrimp pond effluents as the most common complaint [5,11-13]. This activity depends directly or indirectly on a range of coastal and marine ecosystem services some of which may be used at rates that are not sustainable [14-16].

Regarding emerging nature of this industry in Iran in recent years, the present status of studies on shrimp farms in the Hormozgan province, ecological community project Tyab shrimp ponds [17] and ecological community project of shrimp farming in the area of Gwatr [18] has been carried out Environmental Impact Assessment to the possibility identify positive or negative effect on the activity aquaculture on pollution emission and resource consumption in the region might detect the environmental impacts of aquaculture. The first step is to evaluate all aspects of sustainable aquaculture [19]. Today, globalscale of uncontrolled development of shrimp farms pollution, coastal environmental effects and the severity of the pollution is so safety and environmental health of the affected shrimp and other diseases in some areas, causing extensive mortality has been occurred for the breeding shrimp [6]. The main objective of this study is surveying changes in environmental condition because effects of biological and non-biological effluents on coastal waters of Chabahar in Gwatr shrimp culture site.

\section{Materials and Methods}

\section{Study area}

Environmental Impact Assessment (EIA) of shrimp farming conducted in Chabahar Gwatr from July to November 2010. EIA were carried out at west Bahokalat shrimp farming centre in the Sistan and Balochestan province, with overall area of 4000 hectares with useful surface about 2500 hectares. This site is located in the eastern border of Iran and the southern margin of the Bahokalat River and Gwatr estuary. The Gwater shrimp culture complex is located at the north west of Bahokalat. This site includes three parts or three phase of shrimp culture field. The part C1, C2 and C3, each part has 39 shrimp farms. The supplying water canal for these three parts has seven miles long, and the farms are located on both sides of the canal. In all, 117 hectares of these farms are located on northern part and 200 hectares, comprising four farms are located on southern side of Gwatr bay.

*Corresponding author: Valiallahi Jalal, Environmental Science Department Shahid Rajaee Teacher Training University, Lavizan, Tehran, Iran, Postal code:1678815811, Tel: +98 212297 0060; E-mail: jvaliallahi@yahoo.com, iraneesd@yahoo.com

Received June 07, 2017; Accepted July 03, 2017; Published July 05, 2017

Citation: Jalal V and Alireza M (2017) Environmental Impact of Shrimp Culture at Gwatr Culture Site in Chabahar, Sistan-Baluchestan Province. J Aquac Res Development 8: 491. doi: 10.4172/2155-9546.1000491

Copyright: () 2017 Jalal V. This is an open-access article distributed under the terms of the Creative Commons Attribution License, which permits unrestricted use, distribution, and reproduction in any medium, provided the original author and source are credited. 


\section{Sampling techniques}

In this study physical, chemical and biological parameters of water at 5 stations were measured.

Replicated surface water samples from 5 representative stations located in the close vicinity of main pollutant sources along 5 following stations, during shrimp cultivating seasons were collected and stored in clean acid-washed polyethylene bottles, following the sampling routines set for water quality studies [20]. These stations are inlet of supplying water channel, drainage channel, and outlet valve, at the estuary and at Gwatr Gulf. After collection and delivery to the laboratory, the water samples were acidified with $\mathrm{HNO}_{3}$ to a $\mathrm{pH}<2$. Prior to the chemical analysis, water samples were filtered through a Whatman glass microfibre filter (GF/C). Finally, in situ measurement of $\mathrm{pH}$ was taken. All analyses were done in duplicate. Temperature and $\mathrm{pH}$ were measured and recorded at the sites. Water temperature and $\mathrm{pH}$ were measured with a $\mathrm{pH}$ meter model WTW-320, respectively 0.01 units of $0.1^{\circ} \mathrm{C}$. Salinity were reported by a handheld meter, salt sampled by using manual measure and was calculated in gram per litter (PPT). For measuring dissolved oxygen in water, Winckler method was used [21]. Nitrogen and phosphorus forms based on complex formation and then reading the absorbance of sample was performed using a spectrophotometer [22].

\section{Results}

Water temperature ranged from $19.5^{\circ} \mathrm{C}$ to $32^{\circ} \mathrm{C}$ in water supplying channel and from $19.7^{\circ} \mathrm{C}$ to $30.7^{\circ} \mathrm{C}$ in main drainage channel, from $22^{\circ} \mathrm{C}$ to $29.7^{\circ} \mathrm{C}$ in outlet drain valve, from $25^{\circ} \mathrm{C}$ to $32.7^{\circ} \mathrm{C}$ in front of Gwatr, and from $23.9^{\circ} \mathrm{C}$ to $31^{\circ} \mathrm{C}$ in the Gwatr Gulf. The difference of average temperature was not significant and in some case, there was minor different between stations $(\mathrm{P} \geq 0.05)$ (Table 1). Water temperature in July was higher than other months, and during the remaining period, it had irregular fluctuations, but generally from spring to winter the trend of temperature was going to downward.

Maximum salinity tolerance observed in the valve outlet and minimum salinity in the Gwatr Gulf. The average salinity was $38.96 \mathrm{ppt}$ during the study. The results of the ANOVA at 5\% level of probability $(P \geq 0.05)$ showed no significant difference in average salinity.

Range of $\mathrm{pH}$ of water in the supplying water canal was from 8.1 to 8.3 , in the channel drainage originally from 7.9 to 8.4 , at the valve outlet from 8.2 to 8.1, at the estuary of Gwatr from 8.1 to 8.2 and at the Gwatr Gulf from 8.1 to 8.4 on the studying period. Average salinity at various stations showed no significant difference (ANOVA, $\mathrm{P} \geq 0.05$ ).

Irregular fluctuations of dissolved oxygen were observed. The range of dissolved oxygen, at supplying water channel was from $4.7 \mathrm{mg} / \mathrm{l}$ to $9.2 \mathrm{mg} / \mathrm{l}$, at drainage channels this range was from $3.5 \mathrm{mg} / \mathrm{l}$ to $8.8 \mathrm{mg} / \mathrm{l}$, and at valve outlet was from $6.9 \mathrm{mg} / \mathrm{l}$ to $10.7 \mathrm{mg} / \mathrm{l}$, at Gwatr was from $7.9 \mathrm{mg} / \mathrm{l}$ to $9.6 \mathrm{mg} / \mathrm{l}$ and at the Gwatr Gulf, was from $5.9 \mathrm{mg} / \mathrm{l}$ to 11.9 $\mathrm{mg} / \mathrm{l}$, the average minimum dissolved oxygen range at the drainage channel was $0.05 \mathrm{mg} / \mathrm{l} \pm 5.84 \mathrm{mg} / \mathrm{l}$. The dissolved oxygen recorded maximum in September and minimum in July at the second station. Average amount of dissolved oxygen in water showed no significant difference between the drainage channel and between other stations $(\mathrm{P} \leq 0.05)$. Average changes in different parameters in this study are shown in Figures 1 and 3.

The amount of total nitrogen at the supplying water channel was from $0.04 \mathrm{mg} / \mathrm{l}$ to $0.1 \mathrm{mg} / \mathrm{l}$, at the main drainage channel was from 0.1 $\mathrm{mg} / \mathrm{l}$ to $1.09 \mathrm{mg} / \mathrm{l}$, the outlet valve to drainage channel was $0.04 \mathrm{mg} / \mathrm{l}$ to $0.30 \mathrm{mg} / \mathrm{l}$. The amount of total nitrogen at Gwatr station was from 0.04 to $0.1 \mathrm{mg} / \mathrm{l}$ and the gulf of Gwatr was from 0.02 to $0.05 \mathrm{mg} / \mathrm{l}$. The results of the ANOVA showed no significant difference in nitrogen at $5 \%$ level of confidence ( $P \geq 0.05)$. A significant difference between the drainage channel and other stations was observed (Duncan test) and a significant difference determined in total phosphorus level of $0.13 \mathrm{mg}$ $\mathrm{L}$ and the lowest $0.04 \mathrm{mg} / \mathrm{l}$ in stations.

For phosphorus, statistical analysis showed that the difference between drainage channel stations with other stations is significant $(\mathrm{P}$ $\leq 0.05$ ). The results of ANOVA showed that in the supplying channel at the liquid waste water output, there wasn't significant difference for Phosphor $(\mathrm{P} \geq 0.05)$. The results for the correlation between the different variables at our studies are shown in Table 1.

\section{Discussion}

Shrimp farm effluents contain high amount of nutrients, organic compounds and other chemicals which discharge to the environment around the farm and can cause undesirable and detrimental effects on the environment to change the plants and animal's composition. The quality of effluent from shrimp farms can be good prospects for sustainable management and provide optimum condition [23]. Minimum air temperature of $21^{\circ} \mathrm{C}$ and $22^{\circ} \mathrm{C}$ in January and maximum air temperature of $34^{\circ} \mathrm{C}$ in spring was observed at Gwatr in Chabahar. In previous studies at the Bahokalat River downstream carried by Khodami [22], minimum and maximum temperature has been reported respectively in January and June. During the breeding periods range of salinity was reported from $37 \mathrm{ppt}$ to $45 \mathrm{ppt}$ at the main drainage channel of change. Salinity of water at shrimp farm are depend on water supply source, these factors depends on seasonal changes, such as physical and chemical characters, evaporation, wind speed and temperature [12].

The results showed that the range of water salinity was from $35 \mathrm{ppt}$ to $41 \mathrm{ppt}$ at supplying water channel. In 1998 the range of salinity from $36 \mathrm{ppt}$ to $45 \mathrm{ppt}$ in supplying water channel of the Gwatr at shrimp ponds has been reported by Khodami [22,23]. Another important factor is the dissolved oxygen which has directly effect on fish growth and metabolism and other environmental conditions. The range of variation in dissolved oxygen at supply water channel is from $4.6 \mathrm{mg}$ to $9.2 \mathrm{mg}$ respectively. The results showed that, during increasing water exchange rate at ponds the amount of oxygen in drainage water channel is less

\begin{tabular}{|c|c|c|c|c|c|c|}
\hline Variable & Temperature $\left({ }^{\circ} \mathrm{C}\right)$ & PH & Salinity (ppt) & Dissolved oxygen (mg) & Total nitrogen (mg) & Total phosphor (mg) \\
\hline Temperature & 1 & & & & & \\
\hline $\mathrm{PH}$ & $0.17^{\mathrm{NS}}$ & 1 & & & & \\
\hline Salinity & $0.15^{\mathrm{NS}}$ & $0.04^{\mathrm{NS}}$ & 1 & & & \\
\hline Dissolved oxygen & $-0.36^{* *}$ & $0.4^{* *}$ & $0.11^{\mathrm{NS}}$ & 1 & & \\
\hline Total nitrogen & $0.06^{\mathrm{NS}}$ & $0.16^{\mathrm{NS}}$ & $0.37^{* *}$ & $0.17^{\mathrm{NS}}$ & 1 & \\
\hline Total phosphor & $-0.15^{\mathrm{NS}}$ & $-0.15^{\mathrm{NS}}$ & $0.4^{* *}$ & $0.19^{\mathrm{NS}}$ & $0.13^{\mathrm{NS}}$ & 1 \\
\hline
\end{tabular}

Table 1: Test results for the correlation between the studied variables ${ }^{* *}$ : significant at $5 \%$ level and NS: no significant difference). 


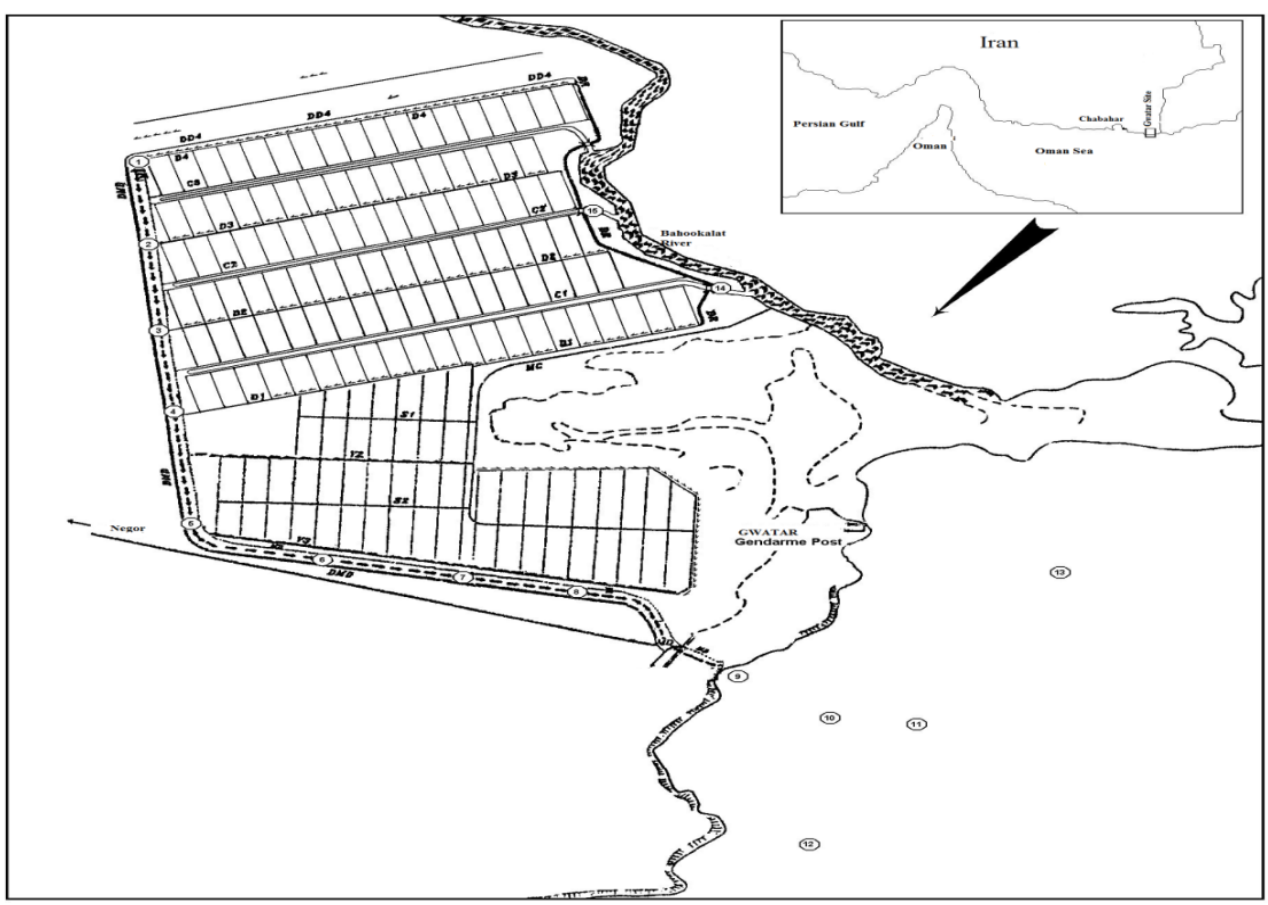

Figure 1: Gwatr shrimp farm complex and sampling stations.

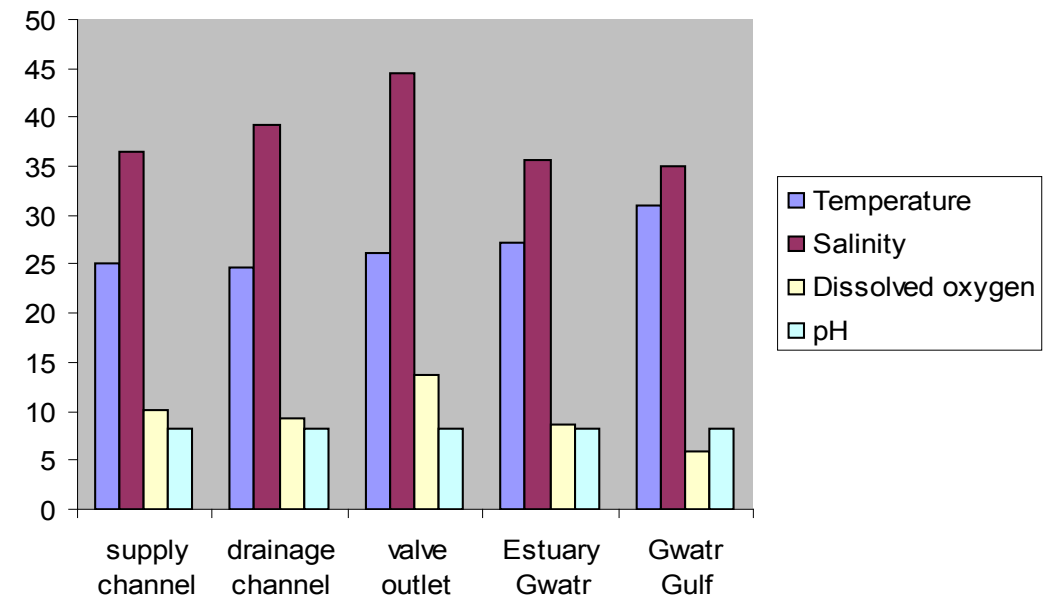

Figure 2: Average change in some parameters of water at different stations.

soluble than the other stations. Changing of the oxygen from station 1 to station 3 declines and the lowest amount was detecting at station 2. Because of discharging wastewater into the Gwatr Gulf, further increasing of consumptions of dissolved oxygen will be occurred and the amount of oxygen will decrease [24]. Comparison of salinity and dissolved oxygen at stations showed that in the drainage channel that drain the Gwatr Gulf salinity, will be increased and dissolved oxygen in water will be reduced, these results is in accordance with finding of Brown [25]. The solubility of oxygen decreases with increasing salinity is consistent. In the Gwatr Gulf, the amount of dissolved oxygen in the months after the monsoon will increase [18].

Many chemical and biological interactions in water are affected by $\mathrm{pH}[26,27]$. Seawater through carbonate a borate buffer system comprises, $\mathrm{pH}$ value of seawater is relatively constant between 8 to 8.5
[23]. The $\mathrm{pH}$ of supplying water channel was from 8.1 to 8.3 in tolerance. The results of the previous of $\mathrm{pH}$ change in the supplying water channel from 8 to 8.3 shows that at the beginning of breeding ponds due to the need for fertilization and development of plankton blooms, $\mathrm{pH}$ increases during the period of the fluctuation [24]. Often monthly average $\mathrm{pH}$ of the drainage channel is in coordinating with the $\mathrm{pH}$ of Gwatr Bay. According to Muluk and partners the pollution resulting from human activities can cause $\mathrm{pH}$ changes in the coastal water [7]. But according to Boyd [28], the $\mathrm{pH}$ of 6 to 9 is suitable for shrimp farms in coastal ecosystems [12]. Total phosphorus concentration measured in the supplying water channel, was significantly lower as $0.01 \mathrm{mg}$ to 0.12 $\mathrm{mg}$ at the main drainage channel and from $0.13 \mathrm{mg}$ to $0.10 \mathrm{mg}$ in the other stations. According to Boyd and Tucker [12] the concentration of total phosphorus from $0.001 \mathrm{mg} / \mathrm{l}$ to $0.01 \mathrm{mg} / \mathrm{l}$ of water, including waste water, can cause plankton to bloom. In all the shrimp farm 


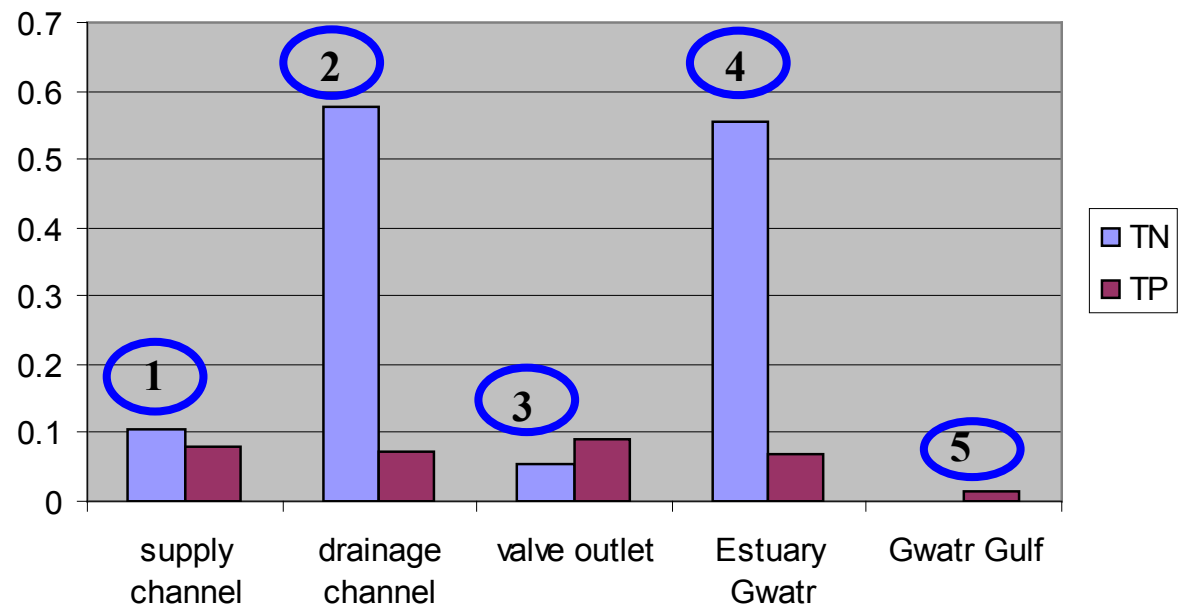

Figure 3: Average change in total phosphorus and total nitrogen in studied stations.

effluent has no effect on the Gwatr Gulf. Only at station in the main drainage channel it has a significant relation with the other stations. Paez and colleagues [28] stated that only $6.1 \%$ of the phosphorus input to the ponds used by the shrimp. Also, the Dierberg and Kiattisimkul [6] believe that $96 \%$ phosphorus inters to the sediment of ponds or wastewaters are located on coastal ecosystem.

Nitrogen is also one of the major shrimp farm effluent wastes [29]. Values of nitrogen indicate that the amount of it in drainage channel and other stations are less and a small amount of it, that reaches to the Gwatr Gulf has no effect on the Gulf.

\section{Conclusion}

It can be concluded that the effluent from shrimp farms have no lethal or irreversible effects on Gwatr environment. So, in present condition in Iran increasing the production rate of Litopenaeus vannamei is suitable. And even better the breeding of this species (according to tolerate low salinity) in the territorial water, and internal baseline, provide solutions for control and reduction of pollutant concentration. In order to monitoring of food intake and the use of fertilizers and effects of intensive production of shrimp, we felt the necessity of monitoring of levels of phosphorus and nitrogen, and more studies in the future. As developing of Gwatr site shrimp culture, increasing of shrimp waste monitoring of may be concentrated on surveying of organic compounds, changes in the composition of plants and animals. However, the activities related to shrimp farming, concentration of nutrients in liquid waste effluent in this area will increased but further increase may be considered as worthy effect on coastal waters. The natural filtration of the estuary is now able to carry biological processes and refining the material, up to the approximate and acceptable concentration in the studied stations in the coastal waters of Gwatr. But receiving excesses liquid waste resulting from increasing activities in this area may have adverse effect on nutrient concentration and other parameters at Gwatr shrimp station and adjacent coastal waters. Intensive shrimp culture in next future must be accomplished by effluents treatment at the outlets of this site, but for now the present situation is in the borderline of WQI (Water Quality Index). Environment capacity of Gwatr for now, due to rising and flocculation of water level, and high self-purification capacity (phyto remediation) acted as a biological filter and prevent adverse environmental impact on the Bay complex at Gwatr bay.

\section{Acknowledgment}

We are honoured to thank of our colleagues in fisheries research centre of Chabahar especially Rezakhah, Azini and Azhdhakoshpor. Special thanks to Dr. Hanieh Saeedi for her critical review of our article.

\section{References}

1. FAO (2012) The State of World Fisheries and Aquaculture. Rome, Italy, Food and Agriculture Organization.

2. Preston NR (2002) The environmental management of shrimp farming in Australia. Report prepared under the world Bank, NACE and FAO.

3. Naylor R, Goldberg R, Mooney H, Beveridge M, Clay J, et al. (1998) Natures subsides to shrimp and salmon farming. Science 2: 883-884.

4. Valiallahi J, Shirazi Gh (2007) Propagation and management of aquaculture and fisheries develop environmental impact assessment. Published Salhein.

5. Boyd CE (2003) Guidelines for aquaculture effluent management at the farm level. Aquaculture 226: 101-112.

6. Dierberg FE, Kiattisimkul W (1996) Issues, impact and implications of shrimp aquaculture in Thailand. Environmental Management 20: 649-666.

7. Muluk C, Bailey C (1996) Social and environment impact of coastal aquaculture in Indonesia 5: 193-209.

8. Jones AB, Preston NP, Dennison WC (2002) The efficiency and condition of oysters and macro algae used as biological filters of shrimp pond effluent Aquaculture Research 33: 1-9.

9. Rob STM, Lawrence AL (1997) Shrimp farms effluent waters, environmenta impact and potential treatment methods. Texas Agriculture Experiment Station Shrimp Mariculture Research. Technical Report 8: 33-58.

10. Sarà G (2007) Ecological effects of aquaculture on living and non-living suspended fractions of the water column: A meta-analysis. Water Research 41: $3187-3200$

11. Anh PT, Kroeze C, Bush SR, Mol APJ (2010) Water pollution by intensive brackish shrimp farming in south-east Vietnam: Causes and options for control. Agricultural Water Management 97: 872-882.

12. Boyd CE, Tucker CS (1998) Pond aquaculture water quality management academic publishers. London, UK.

13. Bui TD, Luong-Van J, Austin CM (2012) Impact of shrimp farm effluent on water quality in coastal areas of the world heritage-listed Ha Long Bay. American Journal of Environmental Sciences 8: 104-116.

14. Naylor RL, Goldburg RJ, Primavera JH (2000) Effect of aquaculture on world fish supplies. Nature 405: 1017-1024.

15. Omidi Q (1998) Input and output water quality of shrimp ponds, Hella site. Fisheries Research Division. 
Citation: Jalal V and Alireza M (2017) Environmental Impact of Shrimp Culture at Gwatr Culture Site in Chabahar, Sistan-Baluchestan Province. J Aquac Res Development 8: 491. doi: 10.4172/2155-9546.1000491

Page 5 of 5

16. Deutsch L, Graslund S, Folke C (2007) Feeding aquaculture growth through globalization: Exploitation of marine ecosystems for fishmeal. Global Environmental Change 17: 238-249.

17. Mortazavi M (1998) Status of shrimp ponds in the province Tyab. Division of Fisheries Research.

18. Khodami Sh (1999) Ecology of the Gwatr Chabahar shrimp ponds. Fisheries Research Division.

19. Black D (2001) Environmental impact of aquaculture. Science direct. Aquaculture 3: 3-9.

20. Clesceri S, Greenberg E, Trussll R (1989) Standard method for the examination of water and waste water. APHA (American Public Health Association), DC, USA.

21. Moopam D (1998) Manual of oceanographic observation on pollutant analysis methods. Ropme, Kuwait.

22. Khodami Sh (2005A) River downstream of limnology Bahokalat. Fisheries Research.
23. Khodami Sh (2005B) Quality of effluent from shrimp farms in Gwatr. Fisheries Research Division.

24. Mokhtari A (2010) Environmental effects of shrimp farming development in Chabahar Gwatr. Thesis Islamic Azad University Banda Abbas.

25. Brown JA, Colling D, Park J, Phillips D, Wright S (1989) Ocean chemistry and deep-sea sediments. Pergamon press. Oxford.

26. Boyd CE (2002) Coastal water quality monitoring in shrimp farming areas, an example from Honduras report prepared under the world bank, NACA, WWF and $\mathrm{FAO}$ consortium program on shrimp farming and the environment work in progress for public discussion. Consortium.

27. Boyd CE, Gautier D (2000) Effluent composition and water quality standards Global Aquaculture 3: 61-66.

28. Paez OF, Guerrero OSB, Buiz FAC (1998) The environmental impact of shrimp aquaculture and the coastal pollution in Mexico. Marine Pollution Bulletin 1: 65-75.

29. Montoya RA, Lawrence A, Grant WE, Velasco M (2002) Simulation of inorganic nitrogen dynamics and shrimp survival in an intensive shrimp culture system. Aquaculture Research 2: 81-94. 